\title{
Comparison between Two Different DNA Extraction Techniques Taken from Buccal Swabs Suitable for Genetic Analyzer
}

\author{
Halah Khalid Ibrahim Al-Sammarraie \\ Forensic DNA Research and Training Center, Al-Nahrain University, Baghdad-Iraq. \\ E-mail: Hala_kh76@yahoo.com.
}

\begin{abstract}
This study aimed to validate two DNA extraction methods collected from buccal cells to gain a genomic DNA and to determine the effect of process time (from collection time to amplification). Total number of 116 buccal swab samples from unrelated healthy volunteers were subjected to DNA extraction by using two methods: modified (phenol chloroform) (Organic) and Prep Filer Forensic DNA Extraction kit. DNA was evaluated according to the: quantity, integrity and suitability for genetic analysis. The DNA yield and purity were measured by Nano drop Spectrophotometer. Organic method was modified from the classical method (addition Dithiothreitol to lysis buffer), The purity average values increased from 1.4 to 1.6 and it had the highest average concentration $(73.3 \mathrm{ng} / \mu \mathrm{l})$ while the highest purity was observed in Prep Filer Forensic DNA Extraction kit with average (1.82). Delayed in sample processing effect both quantity and integrity of the extracted DNA. All samples were genetically analyzed at 16 STR with amelogenin (DNA markers) included in the Amp FISTR ${ }^{\circledR}$ IdentifilerTM PCR Amplification Kit panel from Applied Biosystems. Buccal cell swabs were very good source of genomic DNA especially for large population studies.
\end{abstract}

Keywords: DNA extraction, Buccal cells, quantity, integrity, STR, Genetic analyzer.

\section{Introduction}

With the advances made in the field of molecular biology techniques, the analysis of genomic DNA has become routine work, especially in PCR-based analysis and for large scale genetic or epidemiological population studies [1]. Collection of samples is an important procedure as it takes time and afford needed for medical interference (nurse) [2,3]. In most cases, the preferred source of material from peripheral blood, but it may be problematic in cases some such as extreme illness or elderly people and babies [4]. For these reasons, several protocols have been developed to obtain DNA from buccal cells that are non invasive, easily to collect, store and transport, reliable for forensic or genetic analysis for large population. Many methods for collecting buccal cell samples have been described, including dry procedures using a buccal swab or scraping the oral mucosa, and wet procedures that involve swishing (collut) liquids in the mouth and spitting into a collection vessel [5-6 and 7]. Choose the DNA extraction method is a critical issue as it depends on the source of samples [2]. The use of multiple extraction protocols is laborious, time consuming and expensive [8]. Therefore each lab should validate its laboratory performance of extraction methodologies [9]. One of the most basic and oldest procedures for extraction of DNA from different source of samples is phenol-chloroform isoamyl alcohol (Organic) extraction which is usually used in educational and research field [13, 14 and 15], was modified and compared with Prep FilerTM Forensic DNA-Extraction Kit in which its protocol suitable for the most forensic sample types including stains and swabs of body fluids [9].

Molecular technique require isolation of good quality DNA which is a prerequisite for molecular research. Successful study based on PCR downstream applications requires efficient recovery of good quality and quantity of DNA [8]. DNA typing techniques are one of the most advanced tools for human identification [10]. These sequences are important in genetic mapping, linkage analysis, identity testing in forensic cases, paternity testing, missing persons investigations and mass disaster victim identification [11]. Based upon the variability of several non coding DNA stretches in the human genome, such variable stretches are composed of core units that are repeated 
between 2 to 10000 times, depending on the type of polymorphism short tandem repeat STR [12]. These STR were used as test subject to validate quality of PCR amplification in this study.

\section{Materials and Methods}

In this current study, 116 healthy adult volunteers (age range, 20-55 years) were asked to rinse their mouth with tap water, $30 \mathrm{~s}$ before sampling of buccal swabs to avoid the contamination from food particles. For each individual, both sides of buccal mucosa were wiped with a cotton swab for $15 \mathrm{~s}[16,17]$. All samples were dried at $25^{\circ} \mathrm{C}$ for $1-3 \mathrm{hrs}$ then stored in aseptic paper envelop. If the sample not immediately extracted, it stored at room temperature or cooling condition $\left(4^{\circ} \mathrm{C}\right)$.

Phenol-chloroform protocol was the first choice as a conventional method of extraction; it was modified from the original protocol [14]. The modification included the addition Dithiothreitol (DTT) to the lysis buffer. Twenty buccal swabs were extracted according to the classic method just to compare the result with the modified method. The buccal swabs were suspended in $500 \mathrm{ml}$ of lysis buffer which consisted of $[10 \mathrm{mM}$ Tris HCL (pH 8.0), $10 \mathrm{Mm}$ EDTA, $50 \mathrm{Mm} \mathrm{NaCl}$, 1M Dithiothreitol and 2.0\% SDS], followed by $10 \mu \mathrm{L}$ of $10 \mathrm{mg} / \mathrm{mL}$ proteinase $\mathrm{K}$, mix gently. The samples were incubated at $56^{\circ} \mathrm{C}$ for at least 1 hrs. After digestion, cotton swab substrate were removed with a fresh sterile toothpick or sterile, disposable pipette tip to $0.5 \mathrm{~mL}$ lysed and digested cells and complete the procedure just like the classic method.

The second method used in this study was the commercial kit (Prep Filer Forensic DNA Extraction kit). This protocol was carried out according to manufacturer instructions [9]. DNA concentration and purity were determined by using Nano Drop 2000 (Thermo scientific) spectrophotometer. The integrity and quality of genomic DNA were assessed by electrophoresis on a $0.8 \%$ agarose gel, followed by visualization with ethidium bromide staining. PCR amplification (DNA Typing) of 15 autosomal STR markers were typed along with amelogenin using the Applied Biosystems AmpFlSTR® Identifiler $^{\mathrm{TM}}$ kit, following the protocols described in the User's Manual (Applied Biosystems) [18]. The samples were amplified using verity PCR System (applied Biosystems). Amplification products were diluted 1:15 in $\mathrm{Hi}^{-\mathrm{Di}^{\mathrm{TM}}}$ formamide and GS500-LIZ internal size standard (Applied Biosystems) and analyzed on the 16-capillary 3130XL Genetic Analyzer POPTM4 (Applied Biosystems) was separated on a $36 \mathrm{~cm}$ array. Data were analyzed by Gene Mapperv. 3.2 software (Applied Biosystems, Foster City, CA, USA).

\section{Results and Discussion}

Isolation of a genomic DNA from non invasive is less expensive, easy to collect; transport and store source of samples like buccal cells with adequate molecular weight. It is very important and challenging for reliability of medical, epidemiological and forensic studies. Dithiothreitol (DTT) is frequently used to reduce the disulfide bonds of proteins and peptides. It prevents intramolecular and intermolecular disulfide bonds from forming between cysteine residues of proteins (used in protein separation on gel electrophoresis) [19-20]. DTT was used in lysis buffer to increase purity values and to reduce number of purification by Phenolchloroform, which should be repeated 2-3 times, however using DTT one time was sufficient to give purity result the same result as three times. The purity average of the classical method was (1.4) with range of (1.31.6). I has been noticed that there was an increase in purity results with DTT modification reached (1.6). There was no significant effect on DNA concentration values with or without DTT treatment. In this study, modified Phenol-chloroform method had the highest average concentration $(73.3 \mathrm{ng} / \mu \mathrm{l})$ with regard, the time from collection samples to extraction (1-3) days compared with Prep Filer Forensic DNA Extraction kit Table (1). Organic extraction method worked well for recovery of high molecular weight DNA. This finding is consistent with what have been observed in previous studies [16,21], while the highest purity was noticed in the kit. This type of kits was made for isolation DNA from trace sample (forensic casework) and was 
manufactured to release any inhibiters with high quality. DNA purity values that related with DTT treated-Phenol-chloroform extraction method were increased but still not reached to the kits values this may due to presence of residual organic solvent [14].

Delay of sample processing (from collection to amplification) for any reason like transport samples from other provinces for forensic analysis is very critical to gain a quantity of DNA and integrity. The purity was not affected by delaying process for both methods since it depends on the procedure not on the sample condition (see Table 1 and 2) while the DNA concentrations the current study significantly affected when samples extraction were delayed for one month under room temperature or cooling conditions $\left(4^{\circ} \mathrm{C}\right)$. Obviously the differences appeared in decreasing values in both methods as shown in Table (1).

Table (1)

1-3 Day extraction.

DNA concentration $(\mathrm{ng} / \mu \mathrm{l})$

DNA purity

\begin{tabular}{|c||c||c||c||c||c|}
\hline Method & $* \boldsymbol{N}$ & Range & Average & Range & Average \\
\hline \hline Kit & 40 & $11.2-94$ & 50.5 & $1.5-1.9$ & 1.82 \\
\hline \hline Organic & 40 & $20-155$ & 73.3 & $1.3-1.8$ & 1.6 \\
\hline
\end{tabular}

Table (2)

One month delayed extraction.

DNA concentration

DNA purity

\begin{tabular}{|c||c||c||c|c||c||}
\hline Method & $* \boldsymbol{N}$ & Range & Average & Range & Average \\
\hline \hline Kit & 18 & $4-89.4$ & 42.7 & $1.4-2$ & 1.8 \\
\hline \hline Organic & 18 & $25.2-96.5$ & 50.2 & $1.3-1.7$ & 1.59 \\
\hline
\end{tabular}

*No: Number of samples

DNA Integrity was severely affected by processing delay, the differences observed in band patterns in agarose gel after extraction. No degradation in sample extracted 1-3 days from collection time for both methods as show in Figs. (1 and 2).

The samples were left under room temperature or cooling condition at $4^{\circ} \mathrm{C}$ for one month DNA degradation or absence of bands for both methods were observed (Fig. 3 and 4). Our results agree with most of previous studies [16, 21 and 22].

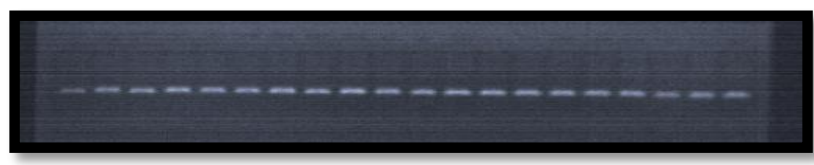

Fig.(1): Gel electrophoresis of DNA Extracted 1-3 days from collection time by Organic (phenol chloroform) extraction method. (Voltage70, Time: 1 hrs, Gel concentration: $0.8 \%$ agarose).

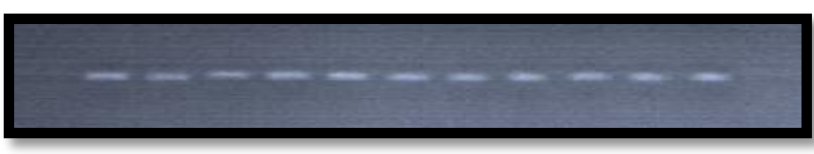

Fig.(2): Gel electrophoresis of DNA Extracted 1-3 days from collection time by PrepFiler Forensic DNA Extraction kit. (Voltage70, Time: 1 hrs, Gel concentration: $0.8 \%$ agarose).

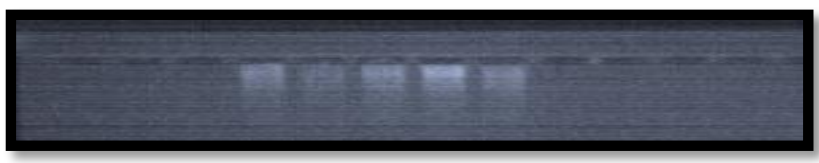

Fig.(3): Gel electrophoresis of DNA Extracted one month delayed extraction from collection time by Organic (phenol chloroform) extraction method. (Voltage 70, Time: 1 hrs, Gel concentration: $0.8 \%$ agarose). 


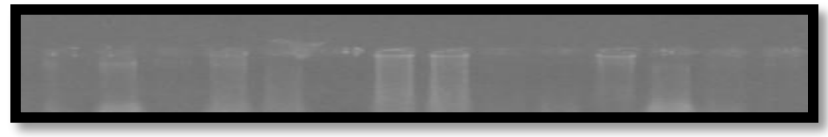

Fig.(4): Gel electrophoresis of DNA Extracted one month delayed extraction from collection time by PrepFiler Forensic DNA Extraction kit. (Voltage 70, Time: 1 hrs, Gel concentration: $0.8 \%$ agarose).

All samples successfully amplified and gave DNA typing profiles Fig.(5) using the AmpFl STR ${ }^{\circledR}$ Identifiler ${ }^{\mathrm{TM}}$ kit for human identification at 16 loci short tandem repeat STR (D3S1358, vWA, FGA, D8S1179, D21S11, D18S51, D5S818, D13S317, D7S820, TH01, TPOX, CSF1PO, D19S433, D2S1338, D16S539, with amelogenin) which was the test subject for evaluation buccal swabs and its suitability to PCR and genetic analyzer. The minimum size allele was the locus D19S433 (101 base pair) and the maximum size allele was the locus D2S1338 (358 base pair) [18].

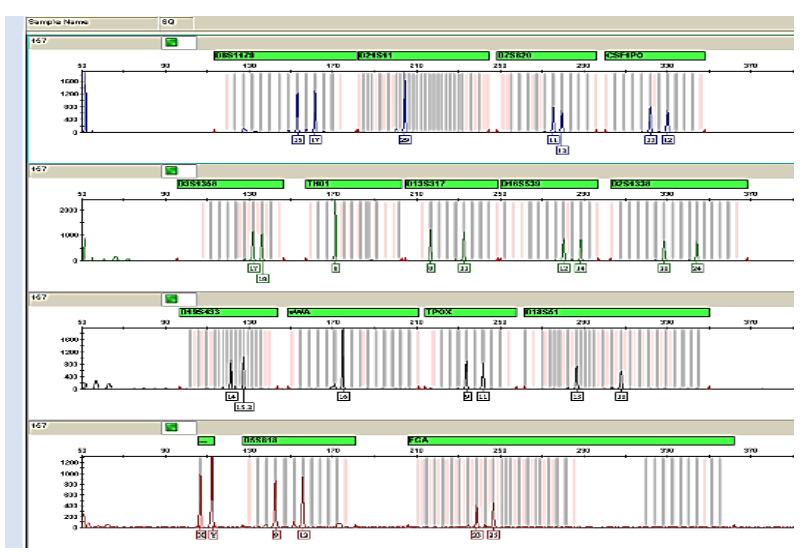

Fig.(5): DNA profile of male showing successful PCR amplification for all 16 loci (allele).

\section{Conclusions}

Buccal swabs can be an alternative method for sampling instead of invasive blood sample collection, cost-effective, simple, rapid, non invasive which give a sufficient quantity and quality of DNA for PCR-based analysis and reliable for forensic data base (archive for DNA profiles) or epidemiological population studies. Modified Phenol- chloroform extraction method is less expensive, save time and effort and reduce risk of contamination. However, it involves the use of toxic chemicals.
Conversely with Prep Filer DNA Forensic Extraction kit is quick, easy, and always efficient (even degraded samples), give high purity but it is very expensive. Both methods are considered efficient for DNA extraction from buccal swab samples.

\section{References}

[1] Satia Abouta, Irena B. King, Mark D. Thornquist, Jeannette Bigler, Ruth E. Patterson, Alan R. Kristal, Ann L. Shattuck, John D. Potter, and Emily White, "Buccal Cell DNA Yield, Quality, and Collection Costs: Comparison of Methods for Largescale Studies", Cancer Epidemiology, Biomarkers \& Prevention, 11,1130-133, 2002.

[2] Marisi A., Sergio Roberto Peres L., "A Simple and Cost-Effective Protocol for DNA Isolation from Buccal Epithelial Cells", Braz Dent J. 18(2): 148-152, 2007.

[3] Alex Livy, Sayhean Lye, Chahil K. Jagdish, Nurul Hanis, Velapasamy Sharmila, Lian Wee Ler, Bagali Pramod, "Evaluation of Quality of DNA Extracted from Buccal Swabs for Microarray Based Genotyping", Ind J Clinical Biochemists, 27(1), 28-33, 2012.

[4] Cozier YC, Palmer JR, Rosenberg L., "Comparison of methods for collection of DNA samples by mail in the Black Women's", Health Study. Ann Epidemiol. 2,117-122, 2007.

[5] King IB, Satia-Abouta J, Thornquist MD, Bigler J, Patterson RE, Kristal AR, Shattuck AL, Potter JD, White E., "Buccal cell DNA yield, quality, and collection costs: comparison of methods for largescalestudies", Cancer Epidemiol Biomarkers Prev, 11, 1130-1133, 2002.

[6] Elizabeth Milne, Frank M. van Bockxmeer, Laila Robertson et al., "Buccal DNA Collection: Comparison of Buccal Swabs with FTA Cards", Cancer Epidemiol Biomarkers Prev, 15, 816-819, 2006.

[7] Van-Wieren-de-Wijer DB, Maitland-vander-Zee AH, de Boer A, et al., "Determinants of DNA yield and purity collected with buccal cell samples". Eur J Epidemiology, 24, 677-682, 2013. 
[8] Khumallambam Devala Devi, Kshetrimayum Punyarani, Nandeibam Samarjit Singh and Huidrom Sunitibala Devi* "An efficient protocol for total DNA extraction from the members of order Zingiberales-suitable for diverse PCR based downstream applications", Springer Plus, 2:669, 2013.

[9] Users manual.prep Filer ${ }^{\mathrm{TM}}$ forensic DNA extraction kit user guide, Applied Biosystems, USA, 2008.

[10] José Arnaldo Soares-Vieira, Ana Elisa Correia Billerbeck, Edna Sadayo Miazato Iwamura, Laís de Almeida Cardoso, Daniel Romero Muñoz, "Post-mortem forensic identity testing: application of PCR to the identification of fire victim". J Rev Paul Med., 118(3), 75-77, 2000.

[11] Mohammed Mahdi AL-Zubaidi, Mohammed Abdul-Daim Saleh and a Salwa Jaber Alawedi., "Genetic Variatrion of 15 Autosomal Short Tandem Repeat (STR) Loci in Sample of Palestinian Population Residing in Iraq" internation al Journal of development research., 4(1)153-156, January, 2014.

[12] Mark Benecke., "DNA typing in forensic medicine and in criminal investigations: a current survey", Natur wissenschaften 84, 181-188, 1997.

[13] Siun Chee Tan and Beow Chin Yiap, "DNA, RNA, and Protein Extraction: The Past and The Present" Journal of Biomedicine and Biotechnology, Article ID 574398, 10 pages doi: 10.1155, 2009.

[14] Sambrook and Russell, Molecular Cloning .Third Edition, Cold Spring Harbour Laboratory Press, New York, 2001.

[15] Hearn R. P, and K. E. Arblaster, DNA Extraction Techniques for Use in Education, Biochemistry and Molecular Biology, 38 (3), 161-166, 2010.

[16] Tsung-Hsing Cheng1, Sheng-Pyng Chen1, Tzu-Chuan Lu2, Wen-Chi Chen3, Jenn-Shing Sher3, and Yi-Shing Shieh, "Optimal DNA Extraction from Buccal SwabSamples", J Med Sci, 30(4), 149-154, 2010.

[17] Juárez-Cedillo, S. Sánchez-García, J.F. Mould-Quevedo, C. García-Peña, J.J. Gallo, F.A. Wagner and G. Vargas-Alarcón,
"Cost-effective analysis of genotyping using oral cells in the geriatric population", Genet. Mol. Res. 9 (3), 1886-1895, 2010.

[18] User's Manual Applied Biosystems, AmpFlSTR $® \quad$ Identifiler ${ }^{\circledR}$ Plus PCR Amplification Kit, Applied Biosystems. Thermo Fisher Scientific, 2015.

[19] Mark P. Molloy, Ben R. Herbert, Bradley J. Walsh' Margaret I. eler, Mathew Traini, Jean-Charles Sanchez, Denis F. Hochstrasser, Keith L. Williams, Andrew A. Gooley' 'Extraction of membrane proteins by differentialsolubilization for separation using two-dimensional gel electrophoresis", Electrophoresis, 19, 837844, 1998.

[20] Frans M. Klis, Marian de Jong, Stanley Brul and Piet W. J. de Groot, "Extraction of cell surface-associated proteins from living yeast cells", Yeast, 24, 253 - 258, 2007.

[21] Souvik Ghatak, Rajendra Bose Muthukumaran, and Senthil Kumar Nachimuthu, "A Simple Method of Genomic DNA Extraction from Human Samples for PCR-RFLP Analysis", Journal of Biomolecular Techniques, 24, 224-231, 2013.

[22] Daniela Straube, Anita Juen, "Storage and shipping of tissue samples for DNA analyses", European Journal of Soil Biology 57, 13-18, 2013.

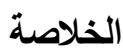

هدفت هذه الدراسة الى تقييم تقنيتين مختلفتين لاستخلاص

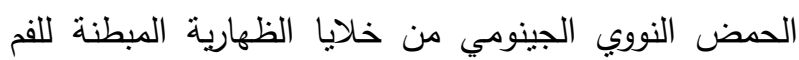
ولتحدديد تاثير الوقت (من جمع العينة الى تضخيمها). جمعت 117 عينة ظهارية من بطانة الفم من اشخاص متطوعين لا تربطهم صلة قرابة اذ استخلصت بطريقيتن:

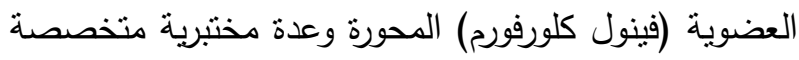

وهي: Prep Filer Forensic DNA Extraction kit تم تقييم الحمض النووي وفق الكمية والنوعية وامكانية استخدامه لاغراض التحليلات الوراثية. تم قياس حصيلة ونقاوة الحمض النووي باستخدام جهاز الطيف المرئي .(Nano drop) 
حورت الطريقة العضوية عن الطريقة التقليدية باضافة مادة Dithiotheritol الى محلول بفر التحليل. زادت معدل النقاوة المستحصلة من ع, إدا الى 1, 1, ومعدل التركيز

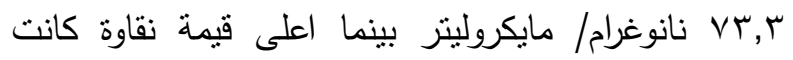

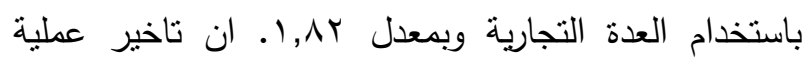
استخلاص العينة اثر على تركيزها وتكاملها.

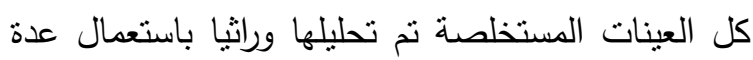
تضخيمية لمؤشرات جسمية خاصة لتحديد التتابعات الوراثية الجنائية. اظهرت الدراسة ان عينات الخلايا الظهارية المبطنة للفم تعتبر مصدرا فعالا للحصول على حمض نووي جينومي خاصة للدراسات المجتمعية الكبيرة. 